\title{
METHOD OF BUILDING MOBILE ORGANIZATIONS IN POLAND
}

\author{
Ewa MASŁYK-MUSIAŁ \\ Faculty of Management \\ Warsaw University of Technology, 02-524 Warszawa, Poland \\ E.Maslyk-Musial@wz.pw.edu.pl
}

\begin{abstract}
We analyse concept of mobile organization which are characterized by personal approach to employees, strategies activating intellectual capital, open and interactive attitude focusing on values like teamwork and trust. Thanks to this, organizations in motion are effective in uncertainty, are better protected against losing and in case of difficulties can faster move on to the winning cycle again. In our project the main question to answer was - if there are any relationships between possessing features of a "young mobile and organization" and its competitive advantage. Based on the theory of managing change [4] it is shown that relationships between strategy, change and managerial competences are crucial for effective change implementation. From the viewpoint of management practice, the indexes developed and presented in this paper can be used to measure youth potential as well can be applied to analyse organizational change and improve the understanding of change among managers. They can be used in organizational audits. Using the indexes, organizations can be divided into Mobile Organizations, open to the environment, that can serve as models to others, and organizations that are more closed, immobile, with low youth potential. The latter require organizational revival projects to be prepared and implemented.
\end{abstract}

Key words: mobile organization, change, youth potential.

\section{Revitalization of organization}

In the conducted research ${ }^{1}$, we were interested in the phenomenon of revitalization, also called rejuvenation of organization, necessary for its effective functioning of business in XXI century. It was assumed that high youth potential is characteristic of the so called mobile organization [7], the antitype to a static organization (remaining motionless). Generally a "mobile organization" has competencies that enable it to maintain or regain the growth stage of lifecycle. To simplify one may say that such an organization is "young" and "open".

Among its main features are:

- openness to environment, sensitivity to new signals and ability of diagnosing new circumstances, continuously being able to generate internal changes as the reaction to the above,

- handling uncertainty by creating people's positive attitudes toward the change,

- extension of „youth" phase by employing managers who have: energy, enthusiasm, courage, fresh look and who generate new ideas,

\footnotetext{
1 Research grant financed by KBN (No 2H02D 004 25) and WSM included: prof. dr hab. Ewa Masłyk-Musiał - leader of the research team, prof. dr hab. Stanisław Sudoł, prof. dr hab. Grażyna Gierszewska, dr hab. Agnieszka Sitko-Lutek, dr Anna Rakowska and mgr Michał Jaksa.
}

- ability to create organizational infrastructure and atmosphere which enable its members to be present in change (at all its stages),

- learning and investing in people as priority, which is transferred for HRD policy,

- implementation of systems which motivate people to be constantly involved in seeking ways of improving themselves and others so that their work is reflected in the companies' growing value.

One can assume that a mobile organization is a company which should be formed and supported in the future. It's able to build competitive advantage over others due to human intellect and profitable investments in the human capital.

In our project the main question to answer was - if there are any relationships between possessing features of a "young mobile and organization" and its competitive advantage. Mobile organizations are typified by strategies based on quality, technology and use of nonmaterial resources. In order to obtain these resources, organizations design motivation and education systems that support changes and constantly observe employees' spirits. The research elaborated also on what the creation of mobile organization depends on and what determines their strategies. It was assumed that the elements essential for the strategists and their strategic choices are: market characteristics, strategic objectives of the company, and implemented or planned structur- 
al/ownership and organizational changes ${ }^{2}$. Attitude to changes is therefore an indirect indication of strategists' preferences for specific strategies in companies.

The assumption made for the research was a relation between:

- type of organization distinguished on the basis of competences in changes, perception of changes, attitude toward changes and behaviour in changes,

- competitive advantage gained as a result of designing and effective implementation of a development strategy of a company.

The concept of mobile organization conveys a link between "the youth potential" and competitive position together with development strategies. It enables effective management under conditions of "general uncertainty" [6] also called "discontinuity management" by Ducker (1999). It also enables mobilization of the rare resources, including the intellectual ones. The concept of MO is useful for explaining activities leading to development of a good market position, choice and determinants of employees' familiarity with strategy, rejuvenating the organization, effective implementation of changes, counteracting to deterioration of managerial competences and maintaining constant readiness for learning, knowledge management, investing in education and building a change culture.

We believe that mobile organizations gain competitive advantage thanks to use of their youth potential. Gaining high youth potential is possible thanks to effective competence management that guarantees appropriate strategic choices, effective change management and achieving strategic objectives even under conditions of distinctive uncertainty.

It can be therefore assumed that the youth potential of mobile organization influences the competitive position of the company and its value for clients (effective implementation of the strategy). The bigger the youth potential is, the more clearly formulated, better executed, and more actively drawing on non-material resources the strategy of the company is.

Mobile organization shall cumulate and express all key elements of efficient management in turbulent environment: adequate reactions to new business situations, ability to learn and systematize knowledge (codification), and ability to search for support of new activities through execution of human resource strategies related

${ }^{2}$ E. Masłyk-Musiał, G. Gierszewska - Strategies of Revitalized Organizations in Poland - Research Result, 22nd EGOS Colloquium Bergen, Norway 6-8 July 2006. with selection of personnel (especially executives), motivating, educating, and building change culture thanks to which employees can identify themselves with the organization often operating in uncertainty.

\section{Subject and scope of research}

The research focused on organizational changes introduced in Polish companies within certain competition strategies and managerial opinion ${ }^{3}$ on the changing process. Both companies and their managers performed in business environment specific for our country in 2004, when for nearly fifteen years the companies had been gathering knowledge about great constitutional and economic transformation. Tangible expressions of these transformations in organizations were multiple restructuring processes often defined as introduction of strategic organizational changes.

Some of researched companies were restructured public enterprises, operating in mature sectors and with a long history (some were set up in the fifties, several even earlier); some of them were new companies, established after 1990 and operating in developing sectors. The latter constituted $64,6 \%$ of the sample group.

We were interested in what happened in the old companies during constitutional transformation and what influenced their present organizational competences and market position. Are companies set up after 1990 characterized by, figuratively speaking, youth, and have the old companies managed to restore this condition which could be proved by energy, fresh perception, creativity and courage of employed executives?

We believed that among both types of companies, the old and the so called rejuvenated, there are ones with characteristics of mobile organizations and competent in change management. We assumed that thanks to their "youth", companies are able to achieve better competitive position. However, not all companies succeeded in "youth" restoration throughout fifteen year period (time between transformation of 1989 and

\footnotetext{
${ }^{3}$ Selection of companies and executives was nonrandom. Research on the subject of changes and competences covered 275 executives and additionally 84 of them answered questionnaires concerning company strategy. Three sorts of questionnaires were used: strategy one was prepared for company strategists, the other two (focusing on 1. executive competences, 2. change and competences issue) were used in interviews with executive personnel being in touch with changes. Researched businesses (40 companies) were chosen among businesses from sectors diversified as to the cycle of life (young and mature sectors) and as to the technological development.
} 
the beginning of the research in 2004). Changes were imposed on them but have not become style of living. A question whether accumulation of knowledge about certain regularities observed in a process of numerous restructuralizations transformed Polish companies into mobile organizations and therefore organizations with huge youth potential seemed to us an intriguing research issue.

In the research it was attempted to estimate the development potential of the companies, and then the relations between this potential and strategies executed for gaining the competitive advantage were analyzed. It was deliberated what strategies should be implemented by a company in order to retain "eternal youth" enabling prolongation of the phase of quick absorbing and generating changes in the life cycle of an organization, and with this - consolidation of the competitive position.

Outcome analysis proved how many possibilities of creating grounds for competitive advantage there are globally, and locally, what can become a success factor for a company and how specific companies with specific development potential can achieve it.

\section{Attitude to changes}

It was assumed that the attitude of respondents toward changes ${ }^{4}$ is a resultant of their perception of situation when changes occur and their competences. Change situation is also defined by: kinds and reasons of changes, participation in changes, change stimulation, perception of forces supporting changes and effects of changes. Owing to the features of particular businesses (like their size, age, business profile, etc.) the strategists' and managers' attitude toward changes will vary. It was also assumed in the research that attitude toward changes influences orientation of strategic choices.

\subsection{Areas and reasons of changes}

According to questioned managers, in 2000 - $2003 \mathrm{nu}-$ merous organizational changes were introduced in companies they were employed in. Implementation of changes was noticed by $95,9 \%$ of respondents. Only $2,3 \%$ of questioned managers believed that their com-

\footnotetext{
4 Report covers the respondents' attitude toward changes implemented in their companies in 2000-2003 and changes planned in 2004-2005.
}

panies were not implementing any changes, and 1,8\% had no opinion on that subject. $84 \%$ of respondents mentioned change planning in $2004-2005$.

Most common areas of changes indicated by the managers as implemented in their companies included: organizational structure $(76,7 \%)$, general strategy $(47,4 \%)$, technology $(46,3 \%)$, motivation systems $(40,7 \%)$, and information-decision systems (36,3\%). Indications in planned changes included: organizational structure $(48,1 \%)$, technology $(43,7 \%)$, informationdecision systems $(35,2 \%)$, functional strategies $(33,0 \%)$ and general strategy $(31,5 \%)$. There is an essential statistical correlation between age of a company and the genre of implemented and planned changes. In reference to implemented changes it concerns functional strategies $(p=0,001)$, technology $(p=0,006)$ and motivation systems $(\mathrm{p}=0,000)$, and in reference to planned changes it concerns organizational structure $(\mathrm{p}=0,000)$.

When analyzing correlation between company age and area of implemented changes, it can be observed that managers employed in middle-aged companies (set up between 1980 and 1989) more likely than managers from young and old companies indicated changes in functional strategies. $66,6 \%$ of respondents from middle-aged companies indicated such changes, while from young businesses only $52,6 \%$ and $31,0 \%$ from the old ones.

Technology changes were most often noticed in old companies $(59,8 \%$ of research sample), meanwhile changes in motivation systems in middle-aged $(53,3 \%)$ and young companies $(51,4 \%)$. Changes in organizational structures were planned first of all in young $(56,1 \%)$ and old companies $(37,9 \%)$. Therefore, in respondents' view old companies changed technology, middle-aged - functional strategies and motivation systems, and in young ones changes in organizational structures were planned. The above indicates that managers distinguish the need of making their businesses more flexible, which involves complementary changes in structures defining shape of an organization. In such cases structural change means improvement of company's openness and entrepreneurial approach.

It is worth noticing that both strategists and managers of changes indicated (first two places) changes in the same areas (see table 1). Respondents listed first of all: organizational structure $(67,9 \%$ of questioned strategists and $76,7 \%$ of managers) and general strategy $(54,8 \%$ and $47,4 \%$ respectively). Further places were 
taken by areas of changes either different in both groups or listed in a different order. For the strategists these are: objectives of organizations, informationdecision systems and changes in management methods, while managers listed: technology, motivation systems and information-decision systems.

Both position occupied in the organizational hierarchy and connected responsibility for changes (role performed in change process) strongly reflect on perception of changes implemented or planned in organizations as well as on assessment of their importance for company's success.

Questioned executives indicated following external factors as mainly inspiring companies to implementing or planning organizational changes (ordered as indicated by the respondents):

- entrance of competitors $-49,6 \%$,

- new, more effective technologies $-44,4 \%$,

- changes in international politics (i.e. entering EU) $34,4 \%$,

- changes in economic management methods and restructuralisation $-28,5 \%$,

- changes in legislation and changes in forms of ownership - $27,4 \%$.

There is a statistically important correlation between company's age and the causes of change like changes in international politics $(p=0,001)$ and new, more effective technologies $(p=0,003)$.

In young companies directors more likely than in others, especially in middle-aged, indicated these particular external causes of change. It can be therefore assumed that young companies are more open to the world and their executives see this openness as an opportunity for their companies' development as well as necessity of change implementation.

However, they are not always able to define the required competences. There is a feeling of readiness to changes in the companies, which is however not necessarily tantamount to the ability of their effective implementation.

Main internal causes of organizational changes indicated by the respondents were:

- too slow development of new products $-34,1 \%$,

- used machinery - $31,1 \%$,

- lowering quality level - 18,5\%,

- decrease in productivity of assets - $18,1 \%$,

- decrease of work effectiveness $-17,4 \%$.
Statistically important correlation is observed between company's age and the internal causes of change like too slow development of new products $(p=0,00)$ and used machinery $(p=0,01)$. The former reason was noted mainly in young companies, the latter in the old ones with used machinery.

Despite large group of respondents who noticed changes in the companies, many executives are not able to see the relation between changes and company's strategy. Over $20 \%$ is not familiar with the latter, which means every fifth respondent. This however does not mean they don't see into the future of the company in bright colours. The analysis of opinions of different management level representatives shows that $76 \%$ of high executives, $64 \%$ of middle management representatives and $45 \%$ of low managerial staff is optimistic about the future of a company (degree of optimism grows with the management rank).

This can be regarded alarming, especially in reference to high executives as exaggerated optimism can be a testament to carelessness or lack of competence (much of a muchness). Strategists' opinions seem to confirm the above, as only in $30 \%$ of businesses a clear strategy has been tracked (meaning cost-leadership, quality or combination strategies), the rest had no coherent strategies or no strategy whatsoever. $16 \%$ of respondents had no information about changes planned in the company in the two proceeding years.

Taking no knowledge about the company's strategy (actually - no strategy at all) into account, it can be assumed that the need to plan changes might not be obvious for part of managing staff. Meanwhile, creation and awareness of a strategy showing direction to company's managers and helping with uncertainty, is a high-priority matter for a company.

Even maintaining current competitive position requires from the executives the ability of strategic thinking and planning changes, not to mention acquiring additional competences for gaining competitive advantage in the future. However, how aware of this are the questioned managers and what are their competences?

\subsection{Participation in change and change competences}

Literature analysis [7] shows that to make changes effective, the companies should have organizational 
Table 1. Comparison of most frequently noticed changes by the respondents performing roles of strategists and managers (in percentage) (source: self study, 2004)

\begin{tabular}{|c|c|c|c|c|c|c|c|}
\hline \multicolumn{6}{|c|}{ Strategists' opinions $(\mathrm{n}=84)$} & \multirow{2}{*}{\multicolumn{2}{|c|}{$\begin{array}{c}\text { Managers' opinions } \\
(\mathrm{n}=272) \\
\begin{array}{c}\text { Organizational } \\
\text { changes }\end{array}\end{array}$}} \\
\hline \multicolumn{2}{|c|}{ Product changes } & \multicolumn{2}{|c|}{$\begin{array}{c}\text { Structural/ownership } \\
\text { changes }\end{array}$} & \multicolumn{2}{|c|}{ Organizational changes } & & \\
\hline $\begin{array}{l}\text { Broadening prod- } \\
\text { uct offer }\end{array}$ & 69,0 & $\begin{array}{l}\text { Changes } \\
\text { of internal structure } \\
\text { of a company }\end{array}$ & 42,9 & $\begin{array}{l}\text { Change of organiza- } \\
\text { tional structure }\end{array}$ & 67,9 & $\begin{array}{l}\text { Organizational } \\
\text { structure }\end{array}$ & 76,7 \\
\hline $\begin{array}{l}\text { Improvement of } \\
\text { product quality }\end{array}$ & 58,2 & $\begin{array}{l}\text { Differentiate } \\
\text { customer service }\end{array}$ & 40,5 & $\begin{array}{l}\text { Change of general } \\
\text { strategy }\end{array}$ & 54,8 & $\begin{array}{l}\text { Change of general } \\
\text { strategy }\end{array}$ & 47,7 \\
\hline $\begin{array}{l}\text { Introduction of } \\
\text { cost monitoring }\end{array}$ & 53,6 & $\begin{array}{l}\text { Eliminating } \\
\text { certain areas } \\
\text { of monitoring }\end{array}$ & 27,4 & $\begin{array}{l}\text { Change of organi- } \\
\text { zation goals }\end{array}$ & 45,2 & New technologies & 46,0 \\
\hline $\begin{array}{l}\text { Developing pro- } \\
\text { motion } \\
\text { and advertising }\end{array}$ & 48,8 & $\begin{array}{l}\text { Improvement of } \\
\text { ownership changes }\end{array}$ & 23,8 & $\begin{array}{l}\text { New information- } \\
\text { decision systems }\end{array}$ & 44,0 & $\begin{array}{l}\text { New motivation } \\
\text { systems }\end{array}$ & 40,7 \\
\hline $\begin{array}{l}\text { Reducing unit } \\
\text { production costs }\end{array}$ & 47,6 & $\begin{array}{l}\text { Creating partner- } \\
\text { ship based on the } \\
\text { company property }\end{array}$ & 22,6 & $\begin{array}{l}\text { Change of man- } \\
\text { agement methods }\end{array}$ & 41,7 & $\begin{array}{l}\text { New information- } \\
\text { decision systems }\end{array}$ & 36,3 \\
\hline
\end{tabular}

competencies in terms of changing that create conditions for participation in changes for employees and especially - managers, and executive competences in changes. Conditions for employees' participation in changes are: encouraging to participate in initializing, designing and other stages of changing, systematic and honest informing employees, developing their abilities to perform at changes (training in changes), effective motivation to changes (gratification for acting the new way). Important organizational competence in preparing for change and ensuring active participation in the change process is creation of change culture awarding values like trust and courage, and behaviours like willingness to take risk and sharing ideas with others, which is necessary for team work and getting satisfaction from implementing changes.

In respondents' opinion, changes were implemented in companies most frequently on board's initiative (88,5\% of indications), executives $(32,6 \%)$ and internal consultants $(19,6 \%)$ or external directors employed for this purpose $(3,7 \%)$. Initiatives from individual employees were very rare $(5,6 \%)$. More often the initiators were employees groups $(10,4 \%)$ or company's specialists $(13,3 \%)$.

Majority of changes were thoroughly prepared, according to $76,7 \%$ respondents ("yes" or "rather yes" responses). Only $16,4 \%$ of respondents believe that the changes were rather unprepared, and 3,9\% find them unprepared. $3 \%$ percent of executives have no opinion on that issue. There is a statistically important correlation between the age of a company and a statement that changes were initiated by consultants $(p=0,002)$ and carefully prepared $(p=0,001)$, and also between size of a company and designing changes $(p=0,03) .25,7 \%$ of executives in young companies point out important role the consultants play in changes, while in the old companies it's respectively $9,2 \%$, and in middle aged companies $6,7 \%$ of questioned directors. In young companies $83,3 \%$ of questioned executives answered affirmatively ("yes" and "rather yes" responses) to questions if change processes in the company are planned carefully and in advance. In middleaged companies this rate was $79,9 \%$ and in old ones $60,5 \%$.

Taking company's age into consideration it can be noticed that $82,1 \%$ of executives from big companies believe that changes and thoroughly prepared ("yes" and "rather yes" responses), in medium-sized companies it is $74 \%$, and in small ones $-72,3 \%$. The conclusion is that in small companies executives rarely find changes thoroughly prepared. The biggest number of respondents participated in implementation stage (86\%) and in preparation of change projects $(70,8 \%)$. Size and age of a company influence participation in change. $77,2 \%$ of questioned executives from big companies indicate their participation in initiating changes.

In medium-sized companies we received such response from $56 \%$ of questioned directors and in small ones from $43 \%$. In general, observation of percentage distribution of executives' responses, allows a notice that 
apart from training stage, where medium-sized companies' directors are more active, the most active executives in the remaining stages are - in the following order - ones from big, medium-sized and small companies. Taking company's age into consideration, we notice that in initializing and implementation stages most active executives come from middle-aged, then young and finally old companies, and in preparation and evaluation stages - executives from respectively young, middle-aged and old companies.

$60,5 \%$ of respondents participated in trainings prior to the changes. This is a pity that this percentage was as low as the participants of trainings evaluated the effectiveness of changes higher, regardless of their own evaluation of usefulness of trainings conducted in relation to changes.

Their participation in trainings prior to changes was described by the respondents as useful (response "very useful" was indicated by $27,2 \%$ of respondents, "useful" - by $50,0 \%$, and "rather useful" - by 19,3\%). Only $3,5 \%$ of respondents found trainings "rather useless". $75 \%$ of respondents indicated that in connection to changes in their companies, the trainings were organized for the whole (or selected) staff, which was con- sidered a very positive phenomenon. Trainings are most often organized in young companies established after 1989. This is a statistically important correlation $(\mathrm{p}=0,01)$.

Every fifth manager in all researched companies responded, however, that training related to introduced changes was not held in their companies, and 5\% of managers answered "I don't know". One fourth of managers, in situation of change implementation, did not observe any high executive's interest in employees' development. This is another indication of insufficient, in several researched companies, information delivered to the employees (in this case trainings are not exploited) about the current situation in the company during organizational changes and not caring about creating effective motivation (including dialogue and trainings) system simultaneously to change implementation.

Organizational competences were indicated by the strategists (strategy interview), and managers' competences were revealed in their auto-evaluation (competency interview). Table 2 presents competences sheet with competences indicated by the research participants supplemented with competences existing in theory of change.

Table 2. Competences sheet - most important organizational competencies, managers' competences in own research (\%) and in theory (source: self study, 2004)

\begin{tabular}{|l|l|l|}
\hline $\begin{array}{c}\text { Organizational competences } \\
\text { important for changes - } \\
\text { researched strategists' opinion }\end{array}$ & $\begin{array}{c}\text { Managerial competences important } \\
\text { for change implementation - } \\
\text { researched managers' opinion }\end{array}$ & $\begin{array}{c}\text { Managerial competences in organi- } \\
\text { zation in motion - theoretical } \\
\text { approach (Kanter, 2001) }\end{array}$ \\
\hline Engaged employees $(41,7 \%)$ & Focus on the future $(65,8 \%)$ & Easy adaptation, flexibility \\
\hline $\begin{array}{l}\text { Effective change management } \\
(39,3 \%)\end{array}$ & Multi aspect approach (50,7\%) & Entrepreneurship and innovation \\
\hline $\begin{array}{l}\text { Effective finance management } \\
(36,9 \%)\end{array}$ & $\begin{array}{l}\text { Developing and mastering employees' } \\
\text { competences }(43,5 \%)\end{array}$ & Knowledge sharing \\
\hline $\begin{array}{l}\text { Feeling of trust and cooperation } \\
(36,9 \%)\end{array}$ & $\begin{array}{l}\text { Discovering new products and markets } \\
(36,7 \%)\end{array}$ & $\begin{array}{l}\text { Facilitating team work and under- } \\
\text { standing other groups contribution to } \\
\text { changes - art of building relations }\end{array}$ \\
\hline Information sharing (31,0\%) & $\begin{array}{l}\text { Social skills like leadership, communica- } \\
\text { tion, conflict solving (34,9\%) }\end{array}$ & $\begin{array}{l}\text { Ability to implement changes effec- } \\
\text { tively - removing obstacles in chang- } \\
\text { ing process }\end{array}$ \\
\hline
\end{tabular}


The above chart shows discrepancies between theorists' opinions (literature studies) and point of view of strategists and managers (research outcome) who often play double role of leaders and change agents, as to the organizational competences and managers' competences that are necessary for efficient change implementation. Theorists' competency list begins with easy adaptation and flexibility, strategists' with engagement of the employees, and managers' with focus on the future. Entrepreneurship and innovation is listed by the theorists on the second position. Managers find competences related to entrepreneurship, like discovering new products and markets as less important and locate them on only the fourth place.

When naming competences indispensable for efficient changes in a company, strategists indicate general idea of creating feeling of trust and engaging employees in change process, and therefore pay attention to personal approach to employees during changes, and care about appropriate use of resources, in particular financial ones, in changes. This means that during changes they focus on: staff, knowledge (effective management) and resources. Mangers look at change implementation from perspective of accomplishing task in changes, which means the most important competences for them are: ability to learn and analyze needs, as well as organizing training processes. Since change process can provoke conflict situations, other important competences indicated by managers were: negotiations and conflict solving.

Despite of different focus, the attitudes to changes expressed by strategists and managers seem to be supplementary.

Competences pointed out by them are compliant with theorists' suggestions that mention following essential abilities for changes: sharing authority (with respect to strategists' suggestions) and ability to build teams and maintain appropriate inter-group relations (with respect to managers' opinion). This data again indicates visible influence of the organizational roles on the opinions about organizational and managers' competences essential for effective changing processes, by assumption related to (but not de facto as according to strategists' responses, in about $70 \%$ of companies, the strategies were not coherent or unspecified) specific development strategies.

The managers' own competences in change management were best evaluated by those from the youngest companies $(28,8 \%)$ set up after 1990 . The worst eval- uation in that category was assigned to the managerial competences in companies established between 1989 and $1990(6,7 \%)$, and a slightly better one to the oldest companies (set up before 1989) - 14,6\%. It can be therefore assumed that managers in young companies have better competences than managers in other organizations. It results from the research that managers believe they are competent in: problem solving and decision making (72,9\% of respondents), predicting and planning $(58,8 \%)$ and using expert knowledge $(58,7 \%)$.

They find these competences sufficient as complex dynamic situations rarely occur in their work. Researched managers indicate that what their tasks require is rather constant learning (48\%) and advancing employees competences $(47,8 \%)$, also maintaining good relationships with business partners $(46,6 \%)$, and not focusing on the future or multi-aspect analysis of decision situations. It was observed that only one fourth of researched group admitted being competent in change management (this refers mainly to young companies important statistical correlation), and only every third respondent would like to improve the competences. Such observation allows assumption concerning dominance of operational orientation over strategic one amid our group of respondents.

\subsection{Effects of changes and their determinants}

In the research we were interested in managerial opinions on the effects of introduced organizational changes. $65,5 \%$ of managers believe that changes ended up successfully. Among young companies managers $70 \%$ assessed the changes ended up successfully. In old companies $57,1 \%$ of respondents believed so, and in middle-aged companies $-46,1 \%$. The biggest number of unsuccessful changes was reported by managers from old companies.

Belief that changes did not end successfully was expressed by only $6,0 \%$ of all respondents. As many as $28,5 \%$ of them (over one fourth) responded "I don't know" or "hard to say", which indirectly shows lack of conviction as to the success of implemented changes. Such opinions appeared mainly in middle-aged companies where over half of managers gave evasive answers like "hard to say". Reasons of such hesitancy can be various but most often are: lack of tools for assessing effects of changes (it is not clear what is actually result of changes and what would have happened in the com- 
Table 3. Factors influencing effective implementation of changes in the opinion of strategists and managers from researched companies (source: self study, 2004)

\begin{tabular}{|l|c|l|c|}
\hline $\begin{array}{c}\text { Factors which influence for the changes effi- } \\
\text { ciency in the opinion of strategists }\end{array}$ & $\begin{array}{c}\text { scale } \\
(1-5)\end{array}$ & $\begin{array}{l}\text { Factors which influence for the changes } \\
\text { efficiency in the opinion of managers }\end{array}$ & $\begin{array}{c}\text { scale } \\
(1-5)\end{array}$ \\
\hline Managers Engagement & 4,28 & Managers Engagement & 4,28 \\
\hline Level of managerial knowledge & 4,09 & Level of managerial knowledge & 3,92 \\
\hline The amount of financial resources & 3,99 & Workers skills & 3,80 \\
\hline Workers skills & 3,78 & The amount of financial resources & 3,65 \\
\hline Understanding of change need by workers & 3,72 & Change scope and depth & 3,53 \\
\hline
\end{tabular}

pany anyway), and no routine informing employees about results of changes. It is therefore clear that managers underestimate motivation as system tool strengthening changing process. Strategists and managers in researched companies indicated different factors that influenced effective change implementation in their companies (table 3).

Order and consequent meaning of these factors for success of changes was established basing on an average from five point scale of influence.

Both strategists and managers indicated involvement (average 4,28 and 4,28 respectively) and level of managerial knowledge $(4,09$ and 3,92) as main factors of change success. On the third place strategists placed financial resources $(3,99)$, while managers - employees' skills $(3,80)$. For managers the scope of changes (scope and depth) was also important $(3,53)$ but for strategist it was more important that the necessity of change was understood by their receivers $(3,72)$ who could thanks to this become allies in change implementation. Thus, strategists and managers agree as to the essence but differ when it comes to details. Again, as when indicating areas of change, there is correlation between the rank of management and roles played in changes, and opinions about them, and this time it refers to change success factors.

\subsection{Stimulating changes}

In successful change management models a correlation between strategy, structure, organizational culture and compensation system oriented to supporting changes is often pointed out. Appropriate connection of these factors in different stages of organization life cycle allows efficient execution of company strategy and achieving better results called change added value (Berger et al., 1994).
$34,8 \%$ of the respondents gave affirmative answers to the question "Are the employees in your company extra rewarded after completing tasks related to changes?". 51,7\% gave negative responses, and 13,5\% had no information on that topic. Managers who noticed correlation between remuneration and tasks accomplished during changes most often named three forms of remuneration encountered in their companies: individual bonuses $(29,3 \%$ of respondents), oral praise $(19,3 \%)$ and special rewards $(14,8 \%)$. In reference to the latter two, a statistically important correlation occurs between them and the age of a company: younger companies more often apply these forms of remuneration in situation of changes.

\section{Indexes of Organizational Youth (IOY)}

Defining the features that describe a mobile organization helped formulate the index defining the potential of organizational youth (POY). POY was developed on the basis of two sub-indexes: Index of Managerial Change Potential (IMCP) and Index of Managerial Youth Potential (IMYP). Together, they determine the potential of organizational youth. The results of these indexes are presented in the table 4.

The Index of Managerial Change Potential (IMCP) was developed on the basis of 10 constituents relating to change and competences, perception of change, attitude o change and motivation to act in this respect. We made an assumption that in mobile organizations the employees see organizational change both as it is implemented and planned, and take a positive view on the effectiveness of the change. The change is extensive and covers various areas of the organization. Managers in the organization are optimistic about its future and are committed to change, feel motivated and the organization invests in their development. 
Table 4. Distribution of sub-index values determining potential of organizational youth of Mobile Organization (POY) (source: self study)

\begin{tabular}{|c|c|c|c|}
\hline 1. & 2. & $1+2$ & POY Level \\
\hline $\begin{array}{c}\text { Index of Managerial } \\
\text { Youth Potential (IMYP) }\end{array}$ & $\begin{array}{c}\text { Index of Managerial } \\
\text { Change Potential (IMCP) }\end{array}$ & $\begin{array}{c}\text { Potential of Organiza- } \\
\text { tional Youth (POY) }\end{array}$ & High \\
\hline H & H & $2 \mathrm{H}$ & Relatively High \\
\hline A & H & H, A & Relatively High \\
\hline H & A & A, H & Average \\
\hline A & A & $2 \mathrm{~A}$ & Average \\
\hline L & H & H, L & Average \\
\hline H & L, $\mathrm{H}$ & Relatively Low \\
\hline A & L & L, A & Relatively Low \\
\hline L & A & A, L & Low \\
\hline L & L & $2 \mathrm{~L}$ & \\
\hline
\end{tabular}

\section{The Index of Managerial Youth Potential (IMYP)} was developed on the basis of five constituents: commitment to change, optimism, indication of significant skills in making change (e.g. focus on the future, discovery of new products, markets, conceptual skills, learning, risk taking), possessing change management competences in self-assessment.

\section{Index of Managerial Change Potential (IMCP)}

1. The results for 40 organizations indicate a relatively low managerial change potential. For 16 companies IMCP is above average and so they can be included among organizations with average change potential. One of the organizations is on the border line of high change potential, and three are above average.

2. It was observed that IMCP is connected $\left(\mathrm{chi}^{2}=\right.$ 0,000 ) with the following features of the respondent organizations:

- scope of business (IMCP is the highest in national organizations),

- type of production (IMCP is the highest in companies engaged in the provision of services and the manufacturing of consumer products),

- legal form (IMCP is the highest in all types of companies and partnerships - limited liability company, joint-stock company and civil partnership and the lowest in state enterprises),

- type of business (higher IMCP is reported in service, financial/insurance and construction/trading organizations),

- age of organization (higher IMCP is reported in young and adult organizations).
3. IMCP is not high in construction organizations (old industry), local organizations and sole proprietorships as well as state enterprises.

4. The percentage distributions show a large number of managers (nearly $60 \%$ ) with low IMCP in old organizations and nearly $50 \%$ in adult organizations.

Given the incidence of low managerial change competences, the above information is hardly good news. While young companies, by effective selection of managers, stand a better chance to rebuild or supplement this potential, the task will not be easy since nearly every third manager has a low IMCP. We have to bear in mind that some of the managers do not know the strategy, have an operational orientation, and are not interested in the future.

\section{Index of Managerial Youth Potential (IMYP)}

1. The other sub-index of the potential of organizational youth is the Index of Managerial Youth Potential. The values reported for IMYP are at an average level. In 4 organizations the index was above average (industry: branch of an IT multinational, medium-sized consumer electronics company, large food products company, medium-sized automobile manufacturing and sales company, however these are different companies than the ones reporting a high IMCP. The highest IMYP index was reported in a large IT company in which the managers scored even the highest level of IMYP. The maximum level of the index was also reported for individual managers in 3 organizations. For other managers in these companies the index was low which is a reflection of large differentiation of ma- 


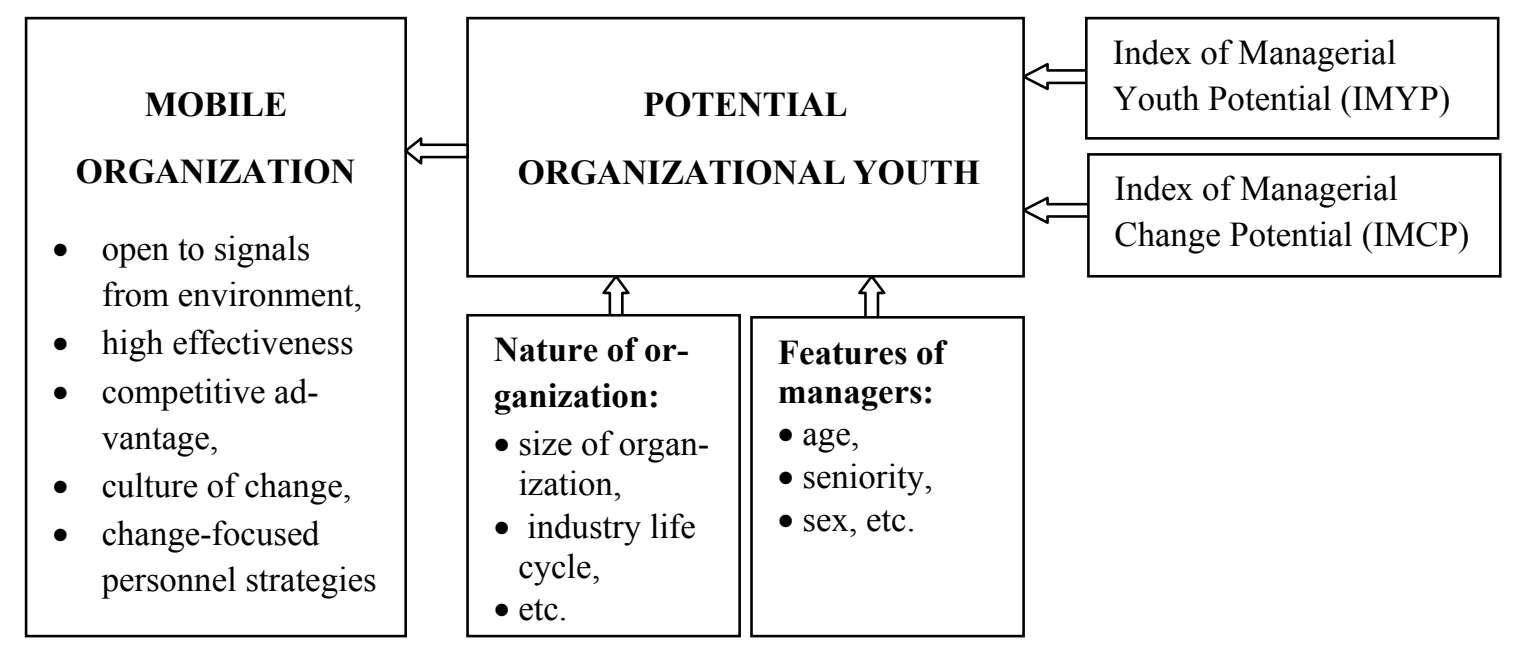

Figure 1. Relations among Variables (source: self study)

nagerial potential in the same organization and perhaps also of the need to change the personnel policy

2. A high IMYP was reported in companies with an average (up to 300) and high (over 301 employees) number of employees. The relationship is statistically significant $\left(\mathrm{chi}^{2}=0,03\right)$. The percentage distribution of managers in a group with high youth potential is as follows: in medium-sized organizations $50,0 \%$, in large $44,7 \%$ and in small $5,3 \%$ of the respondents.

3. The more extensive the scope of business, the higher IMYP $\left(\mathrm{chi}^{2}=0,000\right)$. Organizations in which managers report high IMYP offer services and consumer products $\left(\mathrm{chi}^{2}=0,003\right)$. The type of business includes services and industrial $\left(\mathrm{chi}^{2}=0,000\right)$, with a domination of companies and partnerships $\left(\mathrm{chi}^{2}=\right.$ $0,002)$.

4. At the higher levels of management, managers report a higher IMYP. High IMYP occurs also at lower levels of management and such managers, in our opinion, should be promoted first.

5. Age of Organization. The adult organizations report most managers with a high IMYP $(20,0 \%)$ and in young organizations, set up after 1989, 17,1\% of respondents demonstrate high IMYP. Managers $(45,1 \%)$ in old companies, established prior to 1980 , report a low managerial youth potential.

We made a preliminary assumption in the project that the age of respondent managers and their seniority in the position held may be connected with the Managerial Youth Potential. However the findings of research did not confirm that assumption.
We were also interested in the relationship between IMCP and IMYP which is presented in Table 7.

One quarter of the respondents report both high IMYP and IMCP. The group of mobile managers with change competences and high youth potential in the project is therefore relatively high $\left(\mathrm{chi}^{2}=0,000\right)$.

Still more numerous however is a group reporting low IMYP and IMCP. The most numerous is the group with average IMCP and IMYP. High IMCP is never accompanied by low IMYP. Low IMCP is most often associated with low and average IMYP.

Summing up the analysis of the relationship between the properties of the organization and features of respondent managers, and IMCP and IMYP of the respondents, it should be stressed that there are statistically significant relationships between IMCP and IMYP and certain properties of the organizations and features of their managers. As indicated by the earlier analysis, higher IMCP and IMYP occur more frequently in national organizations set up after 1989, that is in the young organizations.

\section{Index of Organizational Youth (IOY)}

The application of the full IOY helps differentiate organizations in terms of their youth potential, location of the organization on a continuum between mobility and immobility, and then propose a youth maintenance or restoration programme. IOY measuring the potential of organizational youth may help make the management aware of the need to take action to reinstate youth which is necessary for an organization to effectively compete for the customer and be open to the signals from the external environment. 
In order to win battles with competition, organizations must have youthful energy, openness and confidence in themselves, others and the system facilitating, as R. Kanter [5] puts it, practising cooperation, innovation and responsibility.

Over one half of the reviewed organizations demonstrate an average youth potential. Only two organizations have a relatively high IOY and therefore can be recognised as mobile organizations (electronics and IT) and their behaviour in change treated as a model (benchmark) for other companies. These companies are young in two ways: firstly due to the actual age (young branch in Poland) and secondly due to their youth potential.
If we take the change process seriously, then - rather than from imposing ready-made change patterns - we will start the process of change from preparing tailormade projects. This requires a measurement of the potential of organizational youth and stimulation of the interest in change among all the change beneficiaries.

The opening up of an organization to challenges through unleashing human potential is both necessary and the most difficult task for change strategists and leaders.

Table 5. IMCP and Age of Organization (\%) (source: self study)

\begin{tabular}{|l|c|c|c|c|}
\hline Age of Organization & Low & Average & High & TOTAL \\
\hline Old & 57,3 & 40,3 & 2,4 & 100 \\
\hline Adult & 46,7 & 40,0 & 13,3 & 100 \\
\hline Young (set up after 1990) & $\mathbf{3 0 , 7}$ & $\mathbf{5 2 , 8}$ & $\mathbf{1 6 , 5}$ & $\mathbf{1 0 0}$ \\
\hline
\end{tabular}

Table 6. IMYP and Age of Organization (\%) (source: self study)

\begin{tabular}{|l|c|c|c|c|}
\hline Age of Organization & Low & Average & High & TOTAL \\
\hline Old & 45,1 & 48,8 & 6,1 & 100 \\
\hline Adult & 33,3 & 46,7 & 20,0 & 100 \\
\hline Young (set up after 1989) & $\mathbf{2 4 , 0}$ & $\mathbf{5 8 , 9}$ & $\mathbf{1 7 , 1}$ & $\mathbf{1 0 0}$ \\
\hline
\end{tabular}

Table 7. Relationship between level of IMCP and IMYP in respondent managers (\%) (source: self study)

\begin{tabular}{|l|c|c|c|c|}
\hline IMCP & IMYP & Average & High & TOTAL \\
\hline Low & $\mathbf{5 5 , 6}$ & 37,0 & 7,4 & 100 \\
\hline Average & 18,8 & $\mathbf{6 4 , 7}$ & 16,5 & $\mathbf{1 0 0}$ \\
\hline High & 0,0 & 75,8 & $\mathbf{2 4 , 2}$ & 100 \\
\hline
\end{tabular}

Table 8. List of Organizations and IMCP/IMYP Relationships with Other Variables of the Project (source: self study)

\begin{tabular}{|l|l|l|}
\hline Index & $\begin{array}{l}\text { Numbers of highest poten- } \\
\text { tial organizations }\end{array}$ & Statistical relationship between organization potential and properties \\
\hline IMCP & $10,32,38$ & $\begin{array}{l}\text { Scope of business, type of production, form of ownership, type of business, } \\
\text { age of organization }\end{array}$ \\
\hline IMYP & $6,8,11,33$ & $\begin{array}{l}\text { Scope of business, type of production, form of ownership, type of business, } \\
\text { age of organization and size of organization }\end{array}$ \\
\hline
\end{tabular}




\section{Summary}

Mobile organizations are characterized by personal approach to employees, strategies activating intellectual capital, open and interactive attitude focusing on values like teamwork and trust. Thanks to this, organizations in motion are effective in uncertainty, are better protected against losing and in case of difficulties can faster move on to the winning cycle again [5].

From the viewpoint of management practice, the indexes developed, used to measure youth potential, can be applied to analyse organizational change and improve the understanding of change among managers. They can be used in organizational audits.

Using the indexes, organizations can be divided into Mobile Organizations, open to the environment, that can serve as models to others, and organizations that are more closed, immobile, with low youth potential. The latter require organizational revival projects to be prepared and implemented.

The MOs highlighted by the research are young organizations, set up after 1989 and operating in young industries. They have clear (to strategists and managers) development strategies, effectively introduce change, create conditions for everybody to participate in the change process, and invest in staff development. These organizations are open to the future, to constant change.

Organizations with high youth potential employ and develop managers with high youth potential. They select change-focused managers with change management competencies. MOs are aware of the relationship between the strategy and personnel policy. More often than in the other respondent organizations, in parallel with structural change, MOs introduce changes in compensation systems. Development of people is an important management staff appraisal criterion.

Managers have varied management competencies. The worst-performers are the traditional industry managers, while two foreign-owned high-tech companies reported best results. The management in these companies have among others good change management skills, good personality potential and high level of IT application knowledge.

The age of organizations is positively correlated with change management skills and management staff development, which confirms the impact of the new organizational culture; the older organizations still apply the traditional approach to management.
However, part of "traditional" businesses in Poland remains under governmental protection and operates in non-modern sectors. They have learned how to resist changes, especially those of which scope and implementation they were not able to influence. In our research on organizational "motion" public enterprises in traditional industries came out slightly worse.

The situation differs in high technology sectors where winning depends on constant search of new, better products, creation of new markets and constant learning. Two companies (codes as: F06 - utility electronics, and F33 - informatics) that can be considered organizations in motion operate in such sectors. The companies are young in two dimensions - first of all because of their age (in case of the second company it's not the age of the company but of its branch in Poland), and second of all because of their high youth potential.

\section{References}

[1] Bratnicki M. - Zarzqdzanie zmianami $w$ przedsiębiorstwie. Wydawnictwo Akademii Ekonomicznej, Katowice 1997.

[2] Drucker P.F. - Spoleczeństwo postkapitalistyczne. PWN, Warszawa 1999.

[3] Gierszewska G. - Kompetencje strategiczne na poziomie organizacji [in] Zarządzanie kompetencjami w organizacji (ed. Masłyk-Musiał E.). Oficyna Wydawnicza WSM, Warszawa 2005.

[4] Kanter R., Stein B.A., Jick T.D. - The Challenge of Organizational Change. The Free Press, New York 1992.

[5] Kanter R.M. - Confidence. How Winning Streaks and Losing Streaks Begin and End. Crown Business, New York 2004.

[6] Koźmiński A.K. - Zarzadzanie $w$ warunkach niepewności. PWN, Warszawa 2004.

[7] Masłyk-Musiał E. - Organizacje w ruchu. Oficyna Ekonomiczna, Kraków 2004.

[8] Masłyk-Musiał E. (ed.) - Zarzqdzanie kompetencjami w organizacji. WSM, Warszawa 2005.

[9] Poole M.S., Van de Ven A.H., Dooley K., Holmes M.E. - Organization Change and Innovation Process: Theory and Method for Research. Oxford University Press, Oxford 2000. 